\title{
Korelasi Antara Kondisi Keluarga Broken Home dengan Motivasi Belajar Siswa Kelas VIII SMPN 1 Pangkah
}

\author{
Tegar Aji Pamungkas, Kusnarto Kurniawan, Mungin Eddy Wibowo \\ Jurusan Bimbingan dan Konseling Fakultas Ilmu Pendidikan \\ Universitas Negeri Semarang, Indonesia \\ 1tegarajipamungkas@gmail.com., ${ }^{2}$ kusnarto@mail.unnes.ac.id., \\ ${ }^{3}$ mungineddy@mail.unnes.ac.id
}

\begin{abstract}
Abstrak
Motivasi belajar dapat diperoleh dari keluarga. Keluarga yang harmonis dapat menciptakan motivasi belajar yang baik. Namun, di masa modern ini banyak ditemui keluarga yang tidak harmonis. Keadaan tersebut membuat siswa mengalami broken home hingga berakibat menurunnya motivasi belajar. Penelitian ini bertujuan untuk membuktikan adanya hubungan keluarga broken home dengan motivasi belajar siswa. Penelitian ini termasuk penelitian kuantitatif dengan metode expost facto. Populasi dalam penelitian adalah seluruh siswa kelas VIII SMPN 1 Pangkah dengan sampel penelitian kelas 8A, 8D, dan 8I berjumlah 95 siswa. Pengumpulan data dilakukan dengan teknik observasi, pengisian angket, dan skala psikologis. Data yang dikumpulkan kemudian dianalisis dengan uji regresi linier sederhana setelah sebelumnya dilakukan uji normalitas, uji linieritas, dan uji hekteroskedastisitas. Setelah dilakukan pengumpulan data didapat kesimpulan bahwa dari 95 responden, sebanyak 80 responden memiliki keluarga kategori tidak baik dan 5 responden kategori sangat tidak baik. Setelah dilakukan analisis regresi, diketahui bahwa ada hubungan antara keluarga broken home dengan motivasi belajar siswa sebanyak 22,7\% sehingga dapat disimpulkan bahwa terbukti ada hubungan antara kondisi keluarga broken home dengan motivasi belajar siswa kelas VIII SMPN 1 Pangkah.
\end{abstract}

Kata Kunci: Keluarga, Broken Home, Motivasi Belajar

\begin{abstract}
Motivation to learn can be obtained from the family. A harmonious family can create good learning motivation. However, in modern times there are many families who are not harmonious. This situation causes students to experience a broken home which results in decreased motivation to learn. This study aims to prove the relationship between broken home families and student motivation. This research is a quantitative study using the ex post facto method. The population in this study were all students of class VIII SMPN 1 Pangkah with a research sample of class $8 \mathrm{~A}, 8 D$, and $8 I$ totaling 95 students. Data collection was carried out by using observation techniques, filling out questionnaires, and psychological scales. The data collected were then analyzed by simple linear regression test after previously having carried out the normality test, linearity test, and hekteroscedasticity test. After collecting the data, it was concluded that from 95 respondents, 80 respondents had a bad family category and 5 respondents were in very bad category. After the regression analysis was carried out, it was found that there was a relationship between broken home families and student learning motivation as much as $22.7 \%$, so it could be concluded that there was a proven relationship between the condition of the broken home family and the learning motivation of the eighth grade students of SMPN 1 Pangkah.
\end{abstract}

Keyword: Family, Broken Home, Learning Motivation 


\section{Pendahuluan}

Belajar merupakan proses yang dilakukan seseorang untuk memperoleh suatu perubahan tingkah laku yang baru secara keseluruhan, sebagai hasil pengalamannya sendiri dalam interaksi dengan lingkungannya. Keberhasilan sebuah proses belajar ditentukan oleh motivasi diri, lingkungan, dan sarana pendukung. Salah satu faktor penentu keberhasilan belajar yang paling utama adalah adanya motivasi diri untuk belajar dan menguasai sesuatu. Motivasi tersebut dapat terbentuk salah satunya karena adanya dukungan keluarga harmonis karena keluarga harmonis memiliki peran penting dalam pembentukan perilaku seseorang termasuk perilaku belajar seseorang (Kathryn dan David, 2011). Pembentukan perilaku seseorang pertama kali dibentuk dalam keluarga, begitu juga motivasi belajar.

Keharmonisan keluarga bersumber dari kerukunan hidup dalam keluarga. Kerukunan tersebut dapat dilihat dari kebiasaan sesama anggota keluarga seperti adanya hubungan nyata antar anggota keluarga dan adanya hubungan baik terutama dalam hubungan anak dengan orang tua. Hubungan harmonis tersebut membentuk karakter dan kepribadian anak menjadi anak yang baik dan memiliki motivasi tinggi. Sebuah keluarga tergolong dalam keluarga harmoni apabila memenuhi beberapa kualifikasi yaitu menciptakan kehidupan beragama dalam keluarga, mempunyai waktu bersama keluarga, mempunyai komunikasi yang baik antar keluarga, saling menghargai sesama anggota keluarga, kualitas dan kuantitas konflik yang minim, dan adanya hubungan atau ikatan yang erat antar anggota keluarga (Hawari dalam Isminayah, 2016). Saat kualifikasi tersebut terpenuhi, terciptalah keharmonisan keluarga dan keberfungsian dari sebuah keluarga. Keberfungsian inilah yang nantinya mempengaruhi kepribadian anak dalam menjalani kehidupannya termasuk motivasi belajar.

Pada era modern ini keharmonisan keluarga mulai terkikis seiring perkembangan zaman. Tuntutan zaman modern yang semakin sibuk dan hadirnya teknologi yang terkadang menjauhkan yang dekat menjadi satu dari sekian banyak penyebab berkurangnya keharmonisan keluarga. Lambat laun kehidupan keluarga menjadi kacau, tidak teratur dan terarah, hingga akhirnya orang tua kehilangan kewibawaan untuk mengendalikan kehidupan anak-anaknya terutama anak usia remaja. Keadaan tersebutlah yang menimbulkan munculnya keluarga broken home. Secara teori, keluarga broken home dapat diketahui dari dua aspek yaitu: (1) keluarga terpecah karena strukturnya tidak utuh sebab salah satu dari kepala keluarga itu meninggal dunia atau telah bercerai, dan (2) orangtua tidak bercerai akan tetapi struktur keluarga itu tidak utuh lagi karena ayah atau ibu sering tidak dirumah, dan atau tidak memperlihatkan hubungan kasih sayang lagi (Willis, 2011). Saat satu atau kedua aspek tersebut muncul, terciptalah keluarga broken home.

Keadaan keluarga yang broken home banyak terlihat pada siswa di SMPN 1 Pangkah, khususnya kelas VIII. Keadaan siswa yang menunjukkan ciri-ciri keluarga broken home menarik minat peneliti untuk mengetahui apakah ada hubungan antara keluarga broken home dengan motivasi belajar siswa. Mengingat banyak dari siswa yang terindikasi memiliki keluarga broken 
home mengalami motivasi belajar yang rendah. Oleh karena itu, penelitian ini bertujuan untuk mengetahui korelasi/hubungan antara keluarga broken home dengan motivasi belajar siswa.

\section{Metode}

Penelitian ini termasuk penelitian kuantitatif jenis expost facto. Populasi yang ingin diteliti adalah seluruh kelas VIII SMPN 1 Pangkah. Akan tetapi mengingat keterbatasan waktu, diambil sampel secara acak (random sampling) berjumlah 95 siswa dengan rincian kelas 8A (32 siswa), 8D (31 siswa), dan 8I (32 siswa). Pengumpulan data penelitian dilakukan dengan cara melakukan observasi, pengisian angket, dan pengisian skala psikologis. Instrumen penelitian ini berupa pedoman observasi, angket, dan skala psikologis. Seluruh instrumen divalidasi terlebih dahulu sebelum digunakan. Setelah seluruh instrumen dinyatakan valid dan layak, instrumen digunakan untuk mengumpulkan data.

Proses pengumpulan data dilakukan di SMPN 1 Pangkah. Setelah seluruh data terkumpul, dilakukan analisis data. Analisis data menurut Sugiyono (2014) adalah proses mencari dan menyusun secara sistematis data yang diperoleh dari hasil wawancara, catatan lapangan, dan dokumentasi dengan cara mengorganisasikan data ke dalam kategori menjabarkan ke dalam unit-unit, melakukan sintesa, penyusunan ke dalam pola, memilih mana yang penting dan yang akan dipelajari, dan membuat kesimpulan sehingga mudah difahami oleh diri sendiri maupun orang lain. Analisis data pada penelitian ini dilakukan dengan teknik uji asumsi klasik dan regresi linier sederhana. Kedua teknik tersebut dilakukan untuk menguji keabsahan data yang dikumpulkan sekaligus menguji hipotesis yang sebelumnya telah disusun. Hipotesis tersebut yaitu adakah hubungan antara motivasi belajar dengan kondisi keluarga broken home dalam proses pembelajaran SMPN 1 Pangkah.

Analisis data dimulai dengan melakukan uji asumsi klasik. Uji ini terdiri atas tiga bagian yaitu uji normalitas, uji linieritas, dan uji heteroskedastisitas. Apabila data dinyatakan memenuhi kriteria uji asumsi klasik, proses analisis data dilanjutkan dengan melakukan analisis regresi linier sederhana. Analisis ini dilakukan dengan cara melakukan uji korelasi masing-masing prediktor (uji statistik T), uji korelasi simultan (uji statistik F), dan uji koefesien determinasi $\left(\mathrm{R}^{2}\right)$. Seluruh rangkaian analisis tersebut dilakukan dengan bantuan progam IBM SPSS 21.0.

\section{Hasil}

Setelah dilakukan serangkaian proses penelitian, berikut adalah data yang didapatkan.

\section{Gambaran Kondisi Keluarga Siswa Kelas VIII SMPN 1 Pangkah}


Data gambaran kondisi keluarga dikumpulkan dengan menggunakan instrumen penelitian berupa angket yang berisi 20 butir pertanyaan untuk 95 responden. Setelah dilakukan penghitungan hasil pengisian angket, berikut adalah frekuensi dan persentase keseluruhan jawaban responden.

\begin{tabular}{|c|c|c|c|}
\hline Interval Persen & Kriteria & Frekuensi & Persentase \\
\hline $84 \%<\%$ Skor $\leq 100 \%$ & Sangat Baik & 0 & $0.00 \%$ \\
\hline $68 \%<\%$ Skor $\leq 84 \%$ & Baik & 1 & $1.05 \%$ \\
\hline $52 \%<\%$ Skor $\leq 68 \%$ & Cukup & 9 & $9.47 \%$ \\
\hline $36 \%<\%$ Skor $\leq 52 \%$ & Tidak baik & 80 & $84.21 \%$ \\
\hline $20 \% \leq \%$ Skor $\leq 36 \%$ & $\begin{array}{c}\text { Sangat tidak } \\
\text { baik }\end{array}$ & 5 & $5.26 \%$ \\
\hline Jumlah & 95 & $100 \%$ \\
\hline Tertinggi & \multicolumn{2}{|c|}{$70.70 \%$} \\
\hline Terendah & $47.5 \%$ \\
\hline Rata-rata & \multicolumn{3}{|c|}{$4 \%$} \\
\hline
\end{tabular}

Berdasarkan tabel tersebut diperoleh keterangan bahwa tidak ada responden yang memiliki kondisi keluarga sangat baik, 1 responden memiliki kondisi keluarga kategori baik, 9 responden memiliki kondisi keluarga kategori cukup baik, 80 responden memiliki kondisi keluarga kategori tidak baik, dan 5 siswa termasuk dalam kategori sangat tidak baik. Indeks rata-rata persentase kondisi keluarga siswa mencapai $45,4 \%$ sehingga tergolong dalam kategori tidak baik.

\section{Gambaran Motivasi Belajar Siswa Kelas VIII SMP N 1 Pangkah}

Motivasi belajar diukur dengan menggunakan instrumen penelitian berupa angket yang berisi 18 butir pertanyaan untuk 95 responden. Setelah dilakukan penghitungan hasil pengisian angket, didapat data seperti di bawah ini.

\begin{tabular}{|c|c|c|c|}
\hline Interval Persen & Kriteria & Frekuensi & Persentase \\
\hline $84 \%-100 \%$ & Sangat Baik & 0 & $0.00 \%$ \\
\hline $68 \%-84 \%$ & Baik & 7 & $7.37 \%$ \\
\hline $52 \%-68 \%$ & Cukup & 31 & $32.63 \%$ \\
\hline $36 \%-52 \%$ & Tidak baik & 42 & $44.21 \%$ \\
\hline$\leq 36 \%$ & Sangat tidak baik & 15 & $15.79 \%$ \\
\hline Jumlah & 95 & $100 \%$ \\
\hline Tertinggi & \multicolumn{2}{|c|}{$78.7 \%$} \\
\hline Terendah & $22.7 \%$ \\
\hline Rata-rata & \multicolumn{2}{c}{$49.2 \%$} \\
\hline
\end{tabular}


Berdasarkan tabel diatas diperoleh keterangan bahwa tidak ada responden yang memiliki motivasi kategori sangat baik, 7 responden memiliki motivasi belajar kategori baik, 31 responden memiliki motivasi belajar kategori cukup baik, 42 responden memiliki motivasi belajar kategori tidak baik, dan 15 siswa termasuk dalam kategori sangat tidak baik. Rata-rata motivasi belajar yang dimiliki siswa sebesar $49,2 \%$ sehingga dapat disimpulkan bahwa motivasi belajar siswa kelas VIII SMPN 1 Pangkah dalam kategori tidak baik.

Selanjutnya berikut adalah rincian persentase tiap aspek yang ditanyakan pada angket.

Deskripsi Data Variabel Tiap Indikator

\begin{tabular}{|c|l|c|c|c|c|}
\hline No & \multicolumn{1}{|c|}{ Indikator } & $\begin{array}{c}\text { Skor } \\
\text { Empiris }\end{array}$ & $\begin{array}{c}\text { Skor } \\
\text { Ideal }\end{array}$ & $\begin{array}{c}\text { Persentase } \\
\text { skor }\end{array}$ & Kriteria \\
\hline 1 & $\begin{array}{l}\text { Menggap dirinya sama } \\
\text { dengan orang lain }\end{array}$ & 695 & 1900 & $36,58 \%$ & $\mathrm{~TB}$ \\
\hline 2 & $\begin{array}{l}\text { Menenerima kelemahan- } \\
\text { kelemahan yang ada } \\
\text { tanpa menyalahkan orang } \\
\text { lain }\end{array}$ & 737 & 1900 & $38,79 \%$ & $\mathrm{~TB}$ \\
\hline 3 & $\begin{array}{l}\text { Dapat } \\
\text { keadaanemosiyang mengatur } \\
\text { sedang dialami (depresi, } \\
\text { kemarahan) }\end{array}$ & 473 & 1900 & $24,89 \%$ & $\mathrm{STB}$ \\
\hline 4 & $\begin{array}{l}\text { Bersikap baik dan terbuka } \\
\text { dengan keluarga }\end{array}$ & 1544 & 1900 & $81,26 \%$ & $\mathrm{~B}$ \\
\hline \multicolumn{2}{|c|}{ Rata - Rata } & $45,4 \%$ & $\mathrm{~TB}$ \\
\hline
\end{tabular}

Berdasarkan tabel tersebut dapat diketahui bahwa aspek kondisi keluarga memiliki kriteria tidak baik dan sangat tidak baik. Persentase tertinggi terdapat pada keterbukaan dengan keluarga yaitu sebesar $81,26 \%$, sedangkan persentase terendah terdapat pada aspek depresi susah mengontrol emosi yaitu sebesar 24,89\%. Kemudian semua aspek juga memiliki kriteria tidak baik dengan presentase $45,5 \%$. Artinya, aspek kondisi keluarga yang paling banyak dialami oleh siswa kelas VIII SMPN 1 Pangkah adalah mampu berperilaku terbuka dan bersikap baik dengan kelurga, sedangkan aspek kondisi keluarga yang paling sedikit dilakukan yaitu susah mengontrol emosi pada dirinya sendiri dan sering mengakibatkan depresi. Jika dilihat secara keseluruhan, kondisi keluarga pada semua aspek masih dalam kategori normal. 


\section{Hasil Analisis Korelasi Kondisi Keluarga Broken Home terhadap Motivasi Belajar Siswa}

\section{Kelas VIII SMPN 1 Pangkah}

Analisis korelasi dilakukan untuk mengetahui apakah ada hubungan antara kondisi keluarga dengan motivasi belajar siswa. Hubungan tersebut diketahui dengan cara melakukan analisis regresi linier sederhana antara data tingkat kondisi keluarga dan data motivasi belajar. Sebelum melakukan analisis regresi linier sederhana dan menjawab pengujian hipotesis, terlebih dahulu dilakukan uji normalitas, uji linieritas, dan uji heteroskedastisitas. Pengujian tersebut dilakukan menggunakan bantuan program IBM SPSS Statistics versi 21. Berdasarkan pengujian tersebut maka diperoleh hasil sebagai berikut.

Hasil Uji Asumsi Klasik Tingkat Kondisi Keluarga dan Motivasi Belajar

\begin{tabular}{lllcc}
\hline No & Uji Asumsi Klasik & \multicolumn{1}{c}{ Variabel } & Sig & Keterangan \\
\hline 1. & Uji Normalitas & Kondisi Keluarga & $0,101>0,05$ & Normal \\
& & $\begin{array}{l}\text { Tingkat Motivasi } \\
\text { Belajar }\end{array}$ & $0,128<0,05$ & Normal \\
& & $\begin{array}{l}\text { Kondisi Keluarga } \\
\text { Tingkat Motivasi }\end{array}$ & $0,000<0,05$ & Linier \\
2. & Uji Linieritas & $\begin{array}{l}\text { Belajar } \\
\text { Tingkat Motivasi }\end{array}$ & $0,346>0,05$ & $\begin{array}{c}\text { Tidak } \\
\text { heterokedastisitas }\end{array}$ \\
& Uji & Belajar & &
\end{tabular}

Berdasarkan hasil uji normalitas, linieritas, dan heterokedastisitas diketahui bahwa seluruh data memenuhi syarat untuk dilakukan analisis regresi linier sederhana. Setelah dinyatakan memenuhi syarat, data kemudian dianalisis menggunakan analisis regresi linier sederhana untuk menguji hipotesis yang telah disusun yaitu ada hubungan antara kondisi keluarga broken home dan motivasi belajar siswa. Berikut adalah hasil analisis regresi linier sederhana tersebut.

$\mathrm{Ha}$ : Terdapat hubungan tingkat kondisi keluarga broken home terhadap motivasi belajar pada siswa Kelas VIII SMP N 1 Pangkah.

Ho : Tidak terdapat hubungan tingkat kondisi keluarga broken home terhadap motivasi belajar pada siswa Kelas VIII SMP N 1 Pangkah.

Hasil Analisis Regresi Tingkat Kondisi Keluarga Broken Home terhadap Motivasi Belajar

\begin{tabular}{cccccccc}
\hline Prediktor & B & T & Sig (p) & R & $\mathbf{R}^{2}$ & F & Sig (p) \\
\hline (Consta $n t)$ & 230,714 & 21,533 & 0,000 & $0,476^{\mathrm{a}}$ & 0,227 & 93,261 & $0,000^{\mathrm{b}}$
\end{tabular}


Berdasarkan hasil analisis regresi linier sederhana tersebut, diketahui R:0,476, $\rho$ $(0,000)<(\alpha: 0,005)$, dengan demikian Ho ditolak dan Ha diterima. Artinya terdapat hubungan yang signifikan antara tingkat kondisi keluarga broken home terhadap motivasi belajar siswa. Nilai $\mathrm{R}^{2}$ sebesar 0,227 , sehingga terdapat hubungan tingkat kondisi keluarga broken home terhadap motivasi belajar siswa sebesar $22,7 \%$. Meski terbukti ada hubungan kondisi keluarga broken home dengan motivasi belajar siswa, ada 77,3\% faktor lain yang dapat mempengaruhi motivasi belajar siswa.

Persamaan garis regresi: $\mathrm{Y}=230,714-0,470 \mathrm{X} 1$

\section{Pembahasan}

Berdasarkan hasil analisis data yang dilakukan untuk mengetahui hubungan antara kondisi keluarga broken home dengan motivasi belajar siswa didapatkan hasil bahwa terdapat hubungan antara kondisi keluarga broken home dengan motivasi belajar siswa sebanyak 22,7\%. Secara umum, hasil penelitian menunjukkan bahwa kondisi keluarga broken home terhadap motivasi belajar siswa dengan hasil belajar baik dan secara parsial maupun secara bersamasama memiliki pengaruh yang signifikan. Keadaan tersebut terlihat dari hasil uji hipotesis secara parsial antara kondisi keluarga dengan motivasi belajar yang menunjukan adanya pengaruh positif dan signifikanan. Hasil uji hipotesis tersebut berarti bahwa setiap peningkatan variabel kondisi keluarga broken home memiliki pengaruh yang positif dan signifikan terhadap motivasi belajar siswa. Hal ini selaras dengan hasil penelitian Ernawati yang menyimpulkan bahwa keluarga yang memberikan dukungan tinggi terhadap anak akan membuat anak memiliki kepercayaan diri yang tinggi. Hasil deskripsi kondisi keluarga pada tiap variabel menunjukkan bahwa terdapat dua responden yang masuk dalam kriteria tidak baik. Hal tersebut menunjukan bahwa terdapat kondisi keluarga yang tidak harmonis.

Siswa yang hidup di keluarga broken home cenderung memiliki motivasi belajar rendah. Keadaan tersebut sesuai dengan pendapat Hawari (dalam Yusuf, 2009) bahwa individu yang dibesarkan dalam keluarga yang mengalami disfungsi atau tidak harmonis mempunyai resiko pada tumbuh kembang anak seperti memiliki kepribadian anti sosial termasuk didalamnya rendahnya motivasi belajar. Hasil penelitian ini juga sesuai dengan hasil penelitian yang dilakukan Fitri yang mendapatkan simpulan bahwa penerimaan diri sangat berpengaruh terhadap cara seseorang berkomunikasi dan berinteraksi dengan lingkungannya termasuk di dalamnya motivasi belajar. Hadirnya keluarga broken home dapat 
membuat siswa terganggu tumbuh kembangnya, kurang bisa menerima diri, dan akhirnya memiliki motivasi belajar yang rendah. Oleh karena itu, perlu adanya usaha dari orang tau maupun anak untuk bersama-sama menjaga keharmonisan keluarga agar tidak tercipta keluarga broken home. Salah satu caranya dengan melakukan komunikasi antar anggota keluarga karena komunikasi adalah hal yang penting dalam membangun hubungan keluarga (Silaban, 2015).

\section{Simpulan}

Berdasarkan hasil penelitian dan pembahasan mengenai hubungan antara kondisis keluaraga broken home dengan motivasi belajar siswa dapat disimpulkan bahwa terdapat hubungan antara kondisi keluarga broken home dengan motivasi belajar siswa sebanyak 22,7\%. Hasil tersebut menunjukkan bahwa keadaan keluarga yang broken home mempengaruhi motivasi belajar siswa, sehingga perlu adanya kesadaran dari seluruh anggota keluarga untuk menjaga keharmonisan dalam keluarganya.

\section{Daftar Pustaka}

David, Katheryn. 2011. Konseling Keluarga. Yogyakarta: Pustaka Pelajar.

Isminayah, A dan Supandi. 2016. Relasi Tingkat Keharmonisan Keluarga dengan Konsep Diri Remaja. Jurnal Dakwah dan Komunikasi. Hal:236.

Silaban, D. 2015. Komunikasi Antar Pribadi Orang Tua dalam Pembentukan Konsep Diri Remaja pada Keluarga di Lingkungan III Kelurahan Bahu. e-jurnal "Acta Diurna” Vol. IV. No.3.

Sugiyono. 2014. Metode Penelitian Pendidikan (Pendekatan Kuantitatif, Kualitatif, dan R\&D). Bandung: ALFABETA.

Willis, S. 2011. Konseling Keluarga (Family Counseling). Bandung: Alfabeta.

Wills. 2013. Konseling keluarga. Bandung: ALFABETA.

Yusuf, S. 2009. Psikologi Perkembangan Anak dan Remaja. Bandung: PT Remaja Rosdakarya. 